\title{
Artikel
}

\section{Kan de wetgever de werknemers een vaccinatieplicht opleggen?}

\author{
dr. Roland Pierik en prof. mr. Evert Verhulp*
}

In de pers kunnen we steeds vaker lezen dat in andere landen, ook binnen de EU, een verplichting tot vaccinatie voor werknemers wordt overwogen of ingevoerd. ${ }^{1}$ Dat lijkt zeker het geval voor zorgpersoneel. Uit onderzoek van de AWVN blijkt dat een ruime meerderheid van de werkgevers in Nederland het onwenselijk vindt dat ze de vaccinatiestatus van het personeel niet mogen vastleggen. ${ }^{2}$ Onderzoek naar de vraag of werkgevers ook de werknemer willen verplichten zich te vaccineren is ons niet bekend. In de pers zijn wel verschillende voorbeelden genoemd van werkgevers die van hun werknemers een vaccinatiebewijs verlangden. ${ }^{3}$ In deze bijdrage gaan we na of Nederlandse werkgevers hun werknemers kunnen dwingen tot vaccinatie tegen het SARS-CoV-2-virus dat de ziekte COVID-19 veroorzaakt, en of de wetgever wel een dergelijke vaccinatiedwang of -drang aan werknemers kan opleggen. De vraag of de werkgever werknemers kan verplichten een coronatoegangsbewijs te tonen, is reeds aan de orde gesteld door een aantal Leidse collega's. ${ }^{4}$ We laten daarbij in dit artikel de regels uit de AVG onbesproken, nu deze verordening ziet op handhaving en verwerking van gegevens. ${ }^{5}$

* Roland Pierik is UHD rechtsfilosofie. Evert Verhulp is hoogleraar Arbeids recht. Beiden zijn werkzaam bij de Universiteit van Amsterdam.

1 Zie voor een overzicht: D. van Bekkum, 'Meer en meer landen stellen een vaccinatieplicht in. Wat zijn hun overwegingen?', de Volkskrant 29 juli 2021

2 www.awvn.nl/nieuws/in-de-media/werkgevers-vaccinatiestatus-vastleggendeel-werknemers/.

3 www.rtlnieuws.nl/economie/artikel/5251117/bij-leaseplan-alleengevaccineerd-naar-kantoor.

4 Zie G. Boot \& Y. Erkens, 'Werknemer verplichten tot coronatest lijkt juridisch gezien geen bezwaar', Trouw 9 november 2021.

5 Voor discussie over vaccinatieregistratie in de kinderopvang zie: J. Evers, R. Pierik \& M. Verweij, 'De registratie van vaccinatiegegevens in de kinderopvang binnen het regime van de Algemene verordening gegevensbescherming', Privacy \& Informatie, 2019/4, p. 130-136.
We onderzoeken eerst de mededelingen van de Rijksoverheid voor wat betreft de mogelijkheden die de werkgever heeft om de werknemer te dwingen zich te laten vaccineren of om daarop aan te dringen. De overheid draagt het standpunt uit dat de werkgever terzake geen bevoegdheden heeft. Vervolgens kijken we naar grondrechten die in het geding zijn en de weinige rechtspraak die specifiek handelt over inbreuken op deze grondrechten, en ten slotte onderzoeken we of het denkbaar is dat de wetgever kan faciliteren dat de werkgever aan de werknemer wel een vaccinatieplicht kan opleggen.

\section{Mededelingen van de overheid}

De Rijksoverheid laat op haar website ${ }^{6}$ stellig weten dat de werkgever een werknemer niet mag verplichten zich te laten vaccineren tegen corona. Op de site is dikgedrukt de vraag opgenomen: 'Mag ik als werkgever een werknemer verplichten zich te laten vaccineren tegen corona?' In kleinere letters is vervolgens te lezen: 'Nee dit mag niet. Vaccinatie is vrijwillig.' Vervolgens wordt gemeld dat ieder mens zelf mag kiezen of hij/zij een coronavaccinatie neemt en vervolgens is op de site te lezen dat dat recht op vrije keuze wat betreft vaccinaties volgt uit artikel 11 van de Nederlandse Grondwet en artikel 8 EVRM. Er wordt door de overheid tevens gewezen op artikel 58ra Wet publieke gezondheid (Wpg). Dit artikel bepaalt dat werknemers en zelfstandigen die beroeps- of bedrijfsmatig werkzaamheden verrichten in

6

www.rijksoverheid.nl/onderwerpen/coronavirus-vaccinatie/vraag-enantwoord/mag-ik-een-werknemer-verplichten-zich-te-laten-vaccineren (laatst geraadpleegd 16 november 2021). 
voor de coronacheck aangewezen sectoren zoals de horeca, niet verplicht kunnen worden een testbewijs te tonen. De werknemer die de coronacheck bij de klant afneemt, is dus zelf niet verplicht deze te ondergaan. Op de persconferentie van 3 november 2021 heeft de regering aangegeven dit uitgangspunt te willen verlaten, waarover later meer. Uit de informatie op de site van de overheid volgt verder dat het aanpassen van het werk van de ongevaccineerde werknemer, of van de werknemer die niet wil zeggen of hij al dan niet gevaccineerd is, een mogelijkheid is. Kort wordt gewezen op de zorgplicht van de werkgever voor een veilige en gezonde werkomgeving. Als de werkgever over de wijze waarop het werk veilig verricht kan worden er in overleg met zijn werknemer niet uitkomt, hebben werkgever en werknemer de mogelijkheid om naar de rechter te stappen, nog steeds volgens de informatie op de site. De rechter weegt de belangen van de werkgever en de werknemer en kijkt of het verlangen van de werkgever noodzakelijk, proportioneel en subsidiair is.

De Rijksoverheid is dus tamelijk stellig en ziet alleen ruimte om de werkzaamheden van de ongevaccineerde werknemer aan te passen als dat door de omstandigheden noodzakelijk is. De site laat veel vragen onbeantwoord, zoals de vraag of er geen andere maatregelen te treffen zouden zijn als blijkt dat een werknemer ongevaccineerd is en de werkgever daarom vindt dat de werknemer een onaanvaardbaar risico voor zijn eigen gezondheid of die van anderen is. Ook maakt de overheid niet duidelijk of een werkgever een bewijs van vaccinatie kan verlangen. De overheidssite wijst op de mogelijkheid met de werknemer te overleggen, maar wijst er tevens op dat de werknemer niet gehouden is aan de werkgever te vertellen of hij is gevaccineerd. Zijn er geen andere regels die iets van een vaccinatiedrang of -dwang met zich kunnen brengen, of die als voorbeeld kunnen dienen?

Op 24 november 2020 maakte het Ministerie van Sociale Zaken en Werkgelegenheid bekend dat het coronavirus (SARS-CoV-2) is geclassificeerd in categorie 3 biologische agentia. ${ }^{7}$ Op de site zelf wordt uitgelegd wat dat betekent voor werknemers: 'dat specifieke maatregelen moeten worden genomen bij potentiële blootstelling aan het virus en (de classificatie) is voornamelijk bedoeld voor het gericht werken met het virus'. Artikel 4.105 Arbeidsomstandighedenbesluit bepaalt dat het verboden is jonge werknemers te laten werken met biologische agentia van categorie 3 of 4, waarbij het gaat om specifieke blootstelling aan biologische agentia, zoals bij de COVID-19-afdeling van een ziekenhuis. De classificatie lijkt verder van weinig belang voor de rechten van werkgevers of werknemers met betrekking tot vaccinatieplicht. Over een bewijs van vaccinatie wordt niets geregeld.

www.arboportaal.nl/actueel/nieuws/2020/11/23/het-coronavirus-sarscov-2-geclassificeerd-in-categorie-3-biologische-agentia (laatst geraadpleegd 16 november 2021).
In december 2019, een paar maanden voor de coronacrisis uitbrak, hebben Ecorys en Proof op verzoek van het Ministerie van Volksgezondheid, Welzijn en Sport een rapport uitgebracht onder de titel 'Verplichting griepvaccinatie bij zorgwerkers: wenselijk en mogelijk?'.8 In dat rapport wordt gewezen op het Arbobesluit Toxische Stoffen en Biologische Agentia dat bepaalt dat de werkgever 'altijd vaccinatie moet aanbieden tegen ziekten waartegen vaccinatie bestaat en waaraan de werknemer wordt en kan worden blootgesteld'. Dat geldt ook voor het coronavaccin, maar nu de overheid dat vaccin reeds op ruime schaal aanbiedt, mag worden aangenomen dat een werkgever daarmee aan zijn verplichtingen voldoet. In dat rapport wordt, om een vergelijking te kunnen maken met de griepvaccinatie, ook gekeken naar de vaccinatie tegen Hepatitis B. Uit het rapport blijkt dat werknemers die zogenoemde risicohandelingen verrichten maar zich niet laten vaccineren tegen Hepatitis $B$, niet verplicht kunnen worden zich te laten vaccineren, maar wel verplicht kunnen worden om zich elk kwartaal te laten testen op antistoffen. Het rapport vermeldt dat voor werknemers die tot de risicogroep behoren het zich niet laten vaccineren arbeidsrechtelijke gevolgen kan hebben, te weten het niet kunnen uitvoeren van bepaalde taken en mogelijke herplaatsing. ${ }^{9}$ Het rapport bespreekt de in het geding zijnde grondrechten, waarbij de nadruk wordt gelegd op artikel 8 EVRM (recht op respect voor het privéleven, waaronder de fysieke en morele integriteit van de persoon moet worden begrepen $)^{10}$ en artikel 9 EVRM (recht op vrijheid van gedachte, geweten en godsdienst). Vervolgens biedt het een goed overzicht van de toepasselijke wetgeving, zoals de Wet op de beroepen in de individuele gezondheidszorg (Wet BIG), de Wet kwaliteit, klachten en geschillen zorg (Wkkgz) en de Wet publieke gezondheidszorg. Al deze wetten bieden geen wettelijke grondslag voor een verplichte vaccinatie: de laatste wet sluit die - zoals hierboven vermeld tot op heden zelfs uitdrukkelijk uit. Ook de Arbowet komt aan de orde. In die wet is voor de werkgever de verplichting opgenomen te zorgen voor de veiligheid en gezondheid van de werknemers. Volgens het rapport hebben 'daarbij (...) maatregelen gericht op collectieve bescherming voorrang boven maatregelen gericht op individuele bescherming'. ${ }^{11}$ Maar een mogelijkheid om de werknemer te verplichten zich te vaccineren met het griepvaccin zien de onderzoekers met de bestaande regelgeving niet. Dat zal voor het vaccin tegen COVID-19 niet anders zijn.

8 Ecorys en Proof, Verplichting griepvaccinatie bij zorgwerkers: wenselijk en mogelijk? Eindrapportage, Ministerie van Volksgezondheid, Welzijn en Sport, 6 december 2019. www.rijksoverheid.nl/documenten/kamer stukken/2019/12/19/kamerbrief-over-stand-van-zaken-moties-entoezeggingen-vws-kerst-2019 (laatst geraadpleegd 16 november 2021).

9 Verplichting griepvaccinatie bij zorgwerkers: wenselijk en mogelijk?, p. 12.

10 Zie: EHRM 26 maart 1985, $X$ and $Y$ v. the Netherlands, App. no. 8978/80, $\S 22$.

11 Verplichting griepvaccinatie bij zorgwerkers: wenselijk en mogelijk?, p. 53. 


\section{Goed werknemerschap en de werking van grondrechten}

In het algemeen wordt aangenomen dat grondrechten uit de Nederlandse Grondwet geen directe horizontale werking hebben, en dus niet direct van toepassing zijn in de relatie tussen werkgever en een werknemer. Dit impliceert niet dat de grondrechten uit de Grondwet daarmee zonder belang zijn in horizontale verhoudingen: het grondrecht werkt wel degelijk door in de invulling van goed werkgeverschap, dat als het ware met deze grondrechten wordt ingekleurd. Voor deze juridische constructie is gekozen omdat de beperking van grondrechten in horizontale verhoudingen niet goed mogelijk is. Aangenomen wordt dat de Nederlandse grondrechten alleen kunnen worden beperkt door een specifieke wettelijke grondslag en niet door vage of open normen die tot een belangenafweging nopen. ${ }^{12}$ Als een Nederlands grondrecht direct in horizontale verhoudingen zou werken en de beperking van de uitoefening van grondrechten in die verhoudingen alleen zou kunnen plaatsvinden op grond van een specifieke wettelijke grondslag, zou dat de wetgever voor een onmogelijke opdracht stellen. De beoordeling van de beperking van een grondrecht komt uiteindelijk vaak neer op een belangenafweging en een belangenafweging staan de beperkingsclausules van de Nederlandse Grondwet niet toe. Daarom is ervoor gekozen die grondrechten geen horizontale werking toe te kennen. Dat maakt een beroep op artikel 11 Grondwet (onaantastbaarheid van het lichaam) voor de werknemer lastig: hij kan wel een beroep doen op 'de gedachte achter het grondrecht' - in die zin dat van een goed werkgever verlangd mag worden dat hij de fundamentele rechten van een werknemer niet nodeloos beperkt, maar de werknemer kan geen beroep doen op de bepaling zelf. Datzelfde geldt indien de werknemer zich beroept op artikel 9 Grondwet (vrijheid van godsdienst).

Dat is anders voor de grondrechten die uit internationale verdragen voortvloeien. De beperking van dergelijke grondrechten is in het algemeen mogelijk indien die beperking is voorzien bij 'law' en nodig is in een democratische samenleving ter bescherming van, onder andere, de rechten van derden. 'Law' is iedere voor de burger voldoende kenbare regel, die voldoende nauwkeurig is geformuleerd opdat degenen op wie zij van toepassing is, hun gedrag kunnen bepalen en, zo nodig met passende raadgevingen, de gevolgen van een bepaalde handeling redelijkerwijs kunnen overzien. ${ }^{13}$ 'Law' kan op wetgeving of rechtspraak zijn gebaseerd. Ook zonder een wettelijke grondslag kan het beroep op een fundamenteel recht dat is opgenomen in het EVRM, worden be-

12 Zie over de horizontale werking van grondrechten uitvoerig: R. Nehmelman, Staats en bestuursrecht Wetenschap, Horizontale werking van grondrechten, deel 1, algemeen, Deventer: Kluwer 2013.

13 ECHR, Guide on Article 8 of the European Convention on Human Rights, 2021 p. 10, www.echr.coe.int/documents/guide_art_8_eng.pdf (laatst geraadpleegd 3 december 2021). perkt, als dat maar gebeurt op grond van een kenbare regel. Daarom is er geen bezwaar tegen de directe toepassing van dergelijke grondrechten in horizontale verhoudingen, dus tussen werkgever en werknemer. In het Hyatt-arrest ${ }^{14}$ heeft de Hoge Raad overwogen dat artikel 8 EVRM directe werking tussen werkgever en werknemer heeft en kan worden gebruikt om de toelaatbaarheid van een aan de werknemer opgelegde drugstest te beoordelen. Voor die beoordeling volgt de Hoge Raad de bekende viertrapsraket die uit het toetsingsschema van het EHRM voortkomt: (i) dient de inbreuk op de aan de werkneemster toekomende vrijheid een legitiem doel; (ii) is die inbreuk geschikt is om dat doel te bereiken (het noodzakelijkheidscriterium); (iii) is de inbreuk op de persoonlijke levenssfeer van de werknemer evenredig in verhouding tot het bereiken van dat beoogde doel (het proportionaliteitsbeginsel); en ten slotte (iv) kon dit doel niet op een minder ingrijpende wijze kon worden bereikt (het subsidiariteitsbeginsel)? Als deze vragen positief beantwoord worden, is een inperking van een door het EVRM gegeven grondrecht gerechtvaardigd. Deze afweging leidde ertoe dat een hotel te Aruba met een werkneemster kon afspreken dat zij zich 'ad random' zou laten onderwerpen aan een drugstest en dat als die test positief zou zijn, zij de keuze zou hebben tussen het bezoeken van een 'rehabilitatiecentrum' of ontslag op staande voet.

Ook in het geval van een werknemer die een loodtest weigerde te ondergaan terwijl deze werknemer zich daarbij niet op enig ander belang beriep dan 'dat hij niet gehouden is een dergelijke test te ondergaan', ${ }^{15}$ terwijl de werkgever wel een zwaarwegend belang bij het afnemen van die loodtest aanvoerde, leidde tot het oordeel dat de werknemer terecht op staande voet werd ontslagen. De Hoge Raad deed de zaak op grond van artikel 81 Wet RO af. ${ }^{16}$ Wij leiden uit deze rechtspraak af dat het bij de beperking van grondrechten neerkomt op een belangenafweging waarbij de grondrechten wel zwaar wegen, maar niet zonder meer doorslaggevend zijn.

In de hiervoor genoemde gevallen viel de belangenafweging bij deze botsende grondrechten wel uit in het voordeel van de werkgever, maar of dat bij een vaccinatieplicht ook zo zal zijn, is minder evident. Dit omdat de beslissingen in beide gevallen behoorlijk zijn bekritiseerd om de acceptatie van een vergaande inbreuk op de lichamelijke integriteit wegens commerciële belangen. De Hyatt-beslissing past wellicht beter in het land Aruba dan in Nederland. ${ }^{17}$ De maatschappelijke discussie heeft zich ontwikkeld en gaat thans uit van een zwaar-

14 HR 14 september 2007, ECLI:NL:HR:2007:BA5802 (Hyatt).

15 Zie ook de film die Frans Bromet over deze zaak in de serie 'Mijn recht, jouw recht' maakte, te vinden op: youtu.be/-mP9UYsZA3w.

16 HR 30 oktober 2005, ECLI:NL:HR:2005:3193 (Loodtestweigeraar).

17 In deze zin de conclusie van A-G Langemeijer, ECLI:NL:PHR:2007:BA5807, punt 4.27. Zeer kritisch over dit arrest: W.L. Roozendaal, 'Het grondrecht op snuiven, of de grenzen van de gezagsbevoegdheid', ArA 2008, 1 en E. Verhulp, noot bij NJ 2008, 334 (Hyatt/D), minder stellig: H. Voogdsgeerd, 'Hyatt II en de toetsing aan grondrechten bij de uitoefening van de arbeidsovereenkomst', TAC 2021, nr. 1. 
wegend belang van de werknemer die niet wil worden gevaccineerd. Of dat zwaarwegende belang nu is ingegeven door de angst voor bijwerkingen van het vaccin of door principiële bezwaren tegen vaccinatie in het algemeen, lijkt nauwelijks een rol te spelen. Aangenomen wordt thans dat de belangen van de werknemer die tegen vaccinatie of tegen het tonen van een coronabewijs is, zwaarwegend zijn en in beginsel moeten worden gehonoreerd, ${ }^{18}$ hoewel dat op basis van de hiervoor genoemde rechtspraak niet zonder meer kan worden afgeleid.

\section{Schendt een vaccinatiedrang onaantastbaarheid van het lichaam?}

In het Vavřička-arrest van april 2021 oordeelde het Europese Hof voor de Rechten van de Mens (EHRM) dat een kleuterschool kinderen mag weigeren als zij niet gevaccineerd zijn en de overheid wegens het ongevaccineerd laten van een kind een bestuurlijke boete van $€ 400$ aan de ouders mag opleggen. ${ }^{19}$ Het Hof concludeert dat artikel 8 EVRM wordt ingeperkt, maar dat deze inperking gelegitimeerd is. Ze heeft voldoende wettelijke basis, ook al zijn de regels niet alleen in een wet in formele zin vastgelegd, maar ook gedeeltelijk in een Ministeriële regeling. ${ }^{20}$ Van belang is dat het hier gaat om indirecte vaccinatiedrang: de uitsluiting van ongevaccineerde kinderen van de kleuterschool die eindigt op het moment dat de leerplicht ingaat bij het zesde levensjaar. ${ }^{21}$ In deze casus is het dus niet zo dat de vaccinatieplicht zo zwaar weegt dat het de schoolplicht terzijde schuift.

Het Hof stelt dat deze vaccinatiedrang bij kinderen een legitiem doel dient omdat er brede consensus is onder de verdragspartijen, ondersteund door internationale specialistische organisaties als de $\mathrm{WHO}$, dat vaccinatie een van de meest succesvolle gezondheidsinterventies is, ondanks het feit dat dit doel in sommige landen met vrijwillige maatregelen wordt nagestreefd - in Nederland via het Rijksvaccinatieprogramma voor kinderen tot 18 jaar. Het Hof concludeert dat een ruime beoordelingsruimte verdragsluitende partijen de ruimte laat om ook voor meer dwingend vaccinatiebeleid te kiezen. ${ }^{22}$

18

Zie bijv. de reactie van Kitty Jong, vicevoorzitter van FNV op het voorste werkgevers de mogelijkheid te geven een coronapas van de werknemer te controleren: 'Hiermee schend je grondrechten en het leidt tot indirecte vaccinatiedwang', NOS binnenland, 3 november 2021, https://nos.nl/ artikel/2404218-juridische-en-politieke-hobbels-voor-coronapas-opwerk-bedrijven-lijken-verdeeld.

19 EHRM 8 april 2021, Vavřička e.a.vs. Tsjechië, nr. 47621/13, ECLI:CE:ECHR: 2021:0408JUD004762113.

20 R.o. 266-271

21 R.o. 73.

22 R.o. $277,280,310$.
De Tsjechische vaccinatiedrang voor kinderen beantwoordt volgens het Hof ook aan een dringende sociale behoefte: de noodzaak om individuen en de volksgezondheid tegen de betrokken ziekten te beschermen, en een mogelijk dalende vaccinatiegraad bij kinderen tegen te gaan. ${ }^{23}$ Hierbij moet wel worden aangetekend dat in deze uitspraak de verantwoordelijkheid van overheden wordt benadrukt om de 'best interests' van kinderen, individueel en als groep, centraal te stellen bij beslissingen die ook kinderen betreffen, zoals vastgelegd in artikel 3.1 van het Internationaal Verdrag inzake de Rechten van het Kind. ${ }^{24}$ Kinderen kunnen nog niet zelf weloverwogen voor bescherming door vaccinatie kiezen. Het feit dat de overheid mag ingrijpen in de vrijheid van ouders in de keuze voor de vaccinatie van hun kind, betekent niet automatisch dat de overheid ook mag ingrijpen in de vrijheid van juridisch competente volwassenen om de COVID-19-vaccinatie voor zichzelf te weigeren.

\section{Is de reden voor het niet vaccineren van belang?}

In het Vavřička-arrest ziet het Hof geen schending van artikel 9 EVRM (vrijheid van godsdienst en levensovertuiging) omdat de eisers zonder veel argumenten de brede medische consensus ontkenden dat vaccins veilig en effectief zijn. Het Hof concludeert dat het domweg ontkennen van conclusies van gedegen medisch-wetenschappelijk onderzoek, zonder inhoudelijke inbedding in een breder religieus of filosofisch wereldbeeld, onvoldoende kan gelden als samenhangende persoonlijke levensovertuiging om door artikel 9 EVRM te worden beschermd. Volgens vaste jurisprudentie van het EHRM geldt als voorwaarde voor het aanmerken van een samenstel van opvattingen als een godsdienst of levensovertuiging in de zin van artikel 9 EVRM, dat die opvattingen een zeker niveau aan overtuigingskracht, ernst, samenhang en belang bereikt hebben. ${ }^{25}$

De godsdienst of levensovertuiging moet dus ingebed zijn in een breder wereldbeeld, bijvoorbeeld een religieus of antroposofisch wereldbeeld. ${ }^{26}$ Ook wordt een minimale consistentie van opvattingen verwacht om daarop gebaseerde gedragingen of weigeringen door artikel 9 EVRM beschermd te weten. Hieraan wordt niet voldaan als ouders die de overtuiging of godsdienst volgen sommige vaccins wel accepteren en andere niet. ${ }^{27}$

23 R.o. 284

24 R.o. 286-289. Voor een nadere analyse van 'best interests' en 'basic interests' bij vaccinatie voor kinderen zie: R. Pierik 'Vaccination Policies: Between Best and Basic Interests of the Child, Between Precaution and Proportionality', Public Health Ethics, 2020/2, p. 201-214.

25 Bijna letterlijk: ABRvS 15 augustus 2018, ECLI:NL:RVS:2018:2715 (Pastafari).

26 R.o. 335.

27 R.o. 317. 
Zoals gezegd worden de redenen van de weigering om zich te laten vaccineren of om een coronatoegangsbewijs te laten zien in Nederland in belangrijke mate over één kam geschoren. Over het algemeen lijkt het ons ook beter uit de buurt te blijven van een inhoudelijke beoordeling van de reden tot weigering, hoewel daaraan soms niet te ontkomen is ${ }^{28}$ Het toetsen van de oprechtheid van de aangevoerde reden is lastig en de beoordeling van de subjectieve zwaarte voor de betrokkene van de door hem aangevoerde reden is nauwelijks doenlijk. Aan de andere kant kan worden betoogd dat een belangenafweging noopt tot het wegen van de zwaarte van de argumenten van beide partijen en dat sommige argumenten zwaarder zouden moeten wegen dan andere. Er is geen reden om aan te nemen dat de argumentatie die in de Vavřička-zaak wordt gevolgd ook niet in deze context zou gelden. De rechter zal de argumenten van die vaccinatieweigeraars die domweg ontkennen dat vaccins veilig en effectief zijn, minder zwaar kunnen wegen dan die van mensen waarbij de weigering gebaseerd is op gewetensbezwaren die inhoudelijk zijn ingebed in een breder religieus of filosofisch wereldbeeld.

\section{Wat de wetgever mag, mag de werkgever niet...}

In de persconferentie van 2 november 2021 heeft de regering aangekondigd te onderzoeken of een coronatoegangsbewijs ook kan worden ingevoerd voor werknemers in de zorg. ${ }^{29}$ Daarover is ophef ontstaan, omdat een dergelijke regel inbreuk zou maken op de aan werknemers toekomende grondrechten. ${ }^{30}$ Wat daar ook van zij, de vraag die wij ons stellen is of een dergelijke inbreuk door de wetgever juridisch gezien toelaatbaar is. In het Vavřička-arrest van 8 april 2021 erkent het EHRM het belang van vaccinatiewetgeving die bescherming biedt tegen ziekten die een ernstig risico voor de gezondheid kunnen vormen. Dit geldt zowel voor degenen die de betrokken vaccinaties ontvangen als voor degenen die niet gevaccineerd kunnen worden en dus kwetsbaar zijn en voor de bescherming tegen de besmettelijke ziekten in kwestie afhankelijk zijn van een hoge vaccinatiegraad in de samenleving als geheel. Deze doelstelling beantwoordt aan de in artikel 8 EVRM erkende doelstellingen van bescherming van de gezondheid en bescherming van de rechten van anderen. ${ }^{31}$

Zie bijv. de in de vorige noot genoemde beslissing van de Raad van State over de vraag of het pastafarisme een geloof is in de zin van art. 28 lid 3 Paspoortuitvoeringsregeling Nederland 2001 en al eerder HR 31 oktober 1986, ECLI:NL:HR:1986:AC9553 (Zusters van Sint Walburga).

29 www.rijksoverheid.nl/documenten/mediateksten/2021/09/14/letterlijketekst-persconferentie-minister-president-rutte-en-minister-de-jonge14-september-2021.

30 Zie naast voetnoot 13 ook de reactie van Piet Fortuin, de voorzitter van CNV: ('Volgens Fortuin moeten de grondwettelijke rechten gerespecteerd worden'): www.bnr.nl/nieuws/gezondheid/10457478/cnv-geen-coronapasop-de-werkvloer

31 R.o. 272
Anderzijds moet erop gewezen worden dat het in het Vavřička-arrest een ander vaccin betreft dan dat tegen corona en, belangrijker, dat het om kleuters en niet om volwassen werknemers gaat. Ook is van belang dat bij vaccinatie tegen mazelen bij een voldoende hoge vaccinatiegraad een zekere groepsbescherming ontstaat, wat bij de vaccinatie tegen COVID-19 nog verre van zeker is.

Desondanks zijn we het eens met onze Leidse collega's en sluiten ook wij zeker niet uit dat het EVRM ook de juridische ruimte biedt aan de lidstaten om de werknemer te verplichten op de werkplek een coronavaccinatiebewijs te laten zien. ${ }^{32}$ Het EHRM laat de lidstaten nadrukkelijk een zeer ruime beoordelingsvrijheid om zelf wetgeving op het terrein van de gezondheidszorg vast te stellen, en accepteert ook dat sommige landen een vaccinatiedrang invoeren, zelfs als ditzelfde doel in andere landen met vrijwillige maatregelen wordt nagestreefd. Een beperking van een grondrecht wordt door het EHRM als 'noodzakelijk in een democratische samenleving' beschouwd voor het bereiken van een legitiem doel, indien zij beantwoordt aan een 'dringende maatschappelijke behoefte' en, in het bijzonder, indien de door de nationale autoriteiten ter rechtvaardiging aangevoerde redenen 'relevant en toereikend' zijn en indien zij evenredig is aan het nagestreefde legitieme doel. ${ }^{33}$

Op grond van het Vavřička-arrest kan worden geconcludeerd dat een wettelijke indirecte verplichting om zich te laten vaccineren niet inherent in strijd is met het EVRM. In het Vavřička-oordeel ging het om de bescherming van kinderen als groep, inclusief de kinderen die zich om medische redenen niet kunnen laten vaccineren en dus indirect via groepsbescherming beschermd moeten worden. ${ }^{34}$ In het geval van zorgmedewerkers gaat het om de bescherming van patiënten met een kwetsbare gezondheid. In een advies van februari 2021 sprak de Commissie Ethiek en Recht van de Gezondheidsraad de verwachting uit 'dat een vaccinatiebewijs eerder proportioneel is voor (...) beroepen waarbij werknemers in contact komen met ouderen en mensen met een kwetsbare gezondheid. Het moet dan wel evident zijn dat vaccinatie effectief bijdraagt aan de bescherming van deze mensen en er geen minder ingrijpende maatregelen voorhanden zijn. ${ }^{35}$

Er zal dus door de regering nog veel argumentatief werk moeten worden verzet om een eventuele kritische rechter ervan te overtuigen dat vaccinatieplicht op het werk het toetsingsschema van het EHRM kan doorstaan. ${ }^{36}$ Maar zoals staatsrechtgeleerden als Ingrid Leijten on-

32 G. Boot \&Y. Erkens, 'Werknemer verplichten tot coronatest lijkt juridisch gezien geen bezwaar', Trouw 9 november 2021.

33 ECHR (2021). Guide on Article 8 of the European Convention on Human Rights, p. 13; Vavřička, r.o. 273-275.

34 Zie ook r.o. 306.

35 Gezondheidsraad. Ethische en juridische afwegingen COVID-19-vaccinatie. Den Haag: Gezondheidsraad, 2021; publicatienr. 2021/03, p. 27.

36 Zie in dit verband het advies van de Raad voor de Rechtspraak (Spoedadvies Tijdelijke wet uitbreiding coronabewijzen, 17 november 2021) die meent dat 'de afweging van de (bescherming van) diverse grondrechten meer scherpte en duidelijkheid zou moeten krijgen'. 
vermoeibaar blijven benadrukken: grondrechtenbescherming is meer dan de angst om door de Nederlandse of Straatsburgse rechter op de vingers te worden getikt. ${ }^{37}$ Het feit dat staten een ruime beoordelingsmarge hebben, impliceert niet dat de wetgever geen inspanningsverplichting heeft om een maatregel, die zover ingrijpt in de vrijheid van burgers, zo goed mogelijk te rechtvaardigen. Echter, bij zo'n complex vraagstuk, waar heel veel variabelen een rol kunnen spelen om het doel te bereiken, is er geen eenduidig antwoord op de vraag wanneer één specifieke maatregel noodzakelijk en proportioneel is.

Als het daarnaast een maatschappelijk en politiek hoogst omstreden thema is, wordt het van groot belang wie de beslissing neemt. En hier komt de Staten-Generaal als medewetgever in zicht. Een ingrijpende maatregel als de vaccinatieplicht kan doorslaggevend aan legitimiteit winnen als die bij wet in formele zin wordt ingevoerd. Dit waarborgt dat het maatschappelijk debat dat deze maatregel heeft gegenereerd ook in de Tweede en Eerste Kamer gevoerd wordt. Daarmee is de invoering van deze omstreden maatregel in ieder geval zo veel mogelijk publiek gerechtvaardigd, omdat ze door de volksvertegenwoordigers is bediscussieerd én bekrachtigd.

Naar onze mening is daarom het niveau van de formele wetgever - Regering én Staten-Generaal - het juiste niveau om te beslissen over de noodzaak een inbreuk op een aan de werknemer toekomend fundamenteel recht te mogen maken. In het verlengde daarvan ligt het ook minder voor de hand om deze beslissing aan de werkgever over te laten. Zoals Kate Atwell en Mark Navin onlangs in de Amerikaanse context concludeerden: wanneer een bedrijf eist dat zijn werknemers worden gevaccineerd, geeft deze eis uiting aan de particuliere macht van de werkgever over individuele werknemers. ${ }^{38} \mathrm{Het}$ simpele feit dat werkgevers en werknemers door vrijwillige arbeidscontracten met elkaar verbonden zijn, geeft werkgevers geen vrijbrief om medische beslissingen voor hun werknemers te nemen. Het wordt anders wanneer de vaccinatiedrang via de weg van de formele wetgeving ontstaat met instemming van het democratisch verkozen parlement. Politieke beslissingen ontlenen hun legitimiteit aan het feit dat ze de uitkomst zijn van politieke debatten waarin rechten en belangen van individuen en het collectieve belang van de pandemiebestrijding tegen elkaar afgewogen worden. 